\title{
NAQD AL-HADITS SEBAGAI METODE KRITIK KREDIBILITAS INFORMASI ISLAM
}

\author{
Hatta Abdul Malik \\ Universitas Islam Negeri Walisongo Semarang \\ hattaabdulmalik@gmail.com
}

\begin{abstract}
One of the main problems of the information age is how to get the information that would be credible. The issues outlined in this paper, is how naqd al-hadith as a method of criticism credibility of information. The method was used deductive, by discussing the theory of the credibility of the information developed at this time, then discuss the concept of credibility of information on Islam, namely 'ulum al-hadith, then offered naqd alhadith as a method of criticism credibility of information. The results showed that naqd al-hadith can be used as a method of credibility of the information at this time.
\end{abstract}

Keyword: naqd al-hadith, credibility, legal, information

\begin{abstract}
Abstrak
Salah satu problematika utama era informasi ini adalah bagaimana mendapatkan informasi yang dapat dipercaya kebenarannya (kredibel). Persoalan yang diurai dalam tulisan ini, adalah bagaimana naqd al-hadits sebagai metode kritik kredibilitas informasi. metode yang digunakan adalah deduktif, dengan mendiskusikan teori kredibilitas informasi yang berkembang pada saat ini, kemudian mendiskusikan konsep kredibilitas informasi dalam Islam, yaitu 'ulum al-hadits, kemudian menawarkan naqd al-hadits sebagai metode kritik kredibilitas informasi. Hasil penelitian menunjukkan bahwa naqd al-hadits dapat digunakan sebagai metode kredibilitas informasi pada saat ini.
\end{abstract}

Kata kunci: naqd al-hadits, kredibilitas, sahih, informasi

ISSN 2527-8401 (p) 2527-838X (e)

(C) 2016 JISH Pascasarjana UIN Walisongo Semarang

http://journal.walisongo.ac.id/index.php/jish 


\section{Pendahuluan}

Era informasi sekarang ini nampaknya telah diprediksi oleh Alvin Toffler, bahwa manusia dibagi menjadi tiga era: agraris, industri dan informasi. Era informasi yang sedang terjadi sekarang ini ditandai dengan melekatnya teknologi informasi dalam kehidupan dan jumlah ketersediaan informasi yang ada di masyarakat. Selain itu ciri era informasi yang lainnya adalah informasi menjadi komoditi, distribusi informasi berubah dari cetak menjadi elektronik, sistem layanan dari manual menjadi elektronik (e-service), kompetisi bersifat global dan ketat, sektor ekonomi bergeser dari penghasil barang menjadi pelayanan jasa. ${ }^{1}$

John Naisbitt John dalam bukunya "Megatrend" pernah berkata, "We are drowning in information but starved for knowledge". Memang, informasi berlimpah. Sebuah pencarian dengan kata kunci 'agama' di mesin pencari populer google menghasilkan lebih dari 30 juta. Kata kunci 'Allah' sama menghasilkan lebih dari 149 juta, beberapa di antaranya termasuk Allah dalam agama Kristen. Begitu banyak informasi yang tersedia, beberapa pertanyaan mendasar adalah mengenai kegunaan, benar-salah, dan baik-buruk.

Internet telah banyak dipasarkan dengan memberikan jaminan kecepatan dan kemudahan dalam menemukan informasi yang dibutuhkan. Namun kemudahan dan kecepatan informasi yang ditampilkan di internet tidak seluruhnya informasi yang benar, bahkan barangkali salah. Salah informasi di internet disebabkan informasi yang kadaluwarsa, disinformasi maupun miss-informasi. ${ }^{3}$ Bahkan dalam penelitian Nassar disebutkan bahwa 70\% dari pelajar

${ }^{1}$ Ag. Eka Wenats Wuryanta, "Digitalisasi Masyarakat: Menilik Kekuatan Dan Kelemahan Dinamika Era Informasi Digital Dan Masyarakat Informasi," Jurnal Ilmu Komunikasi, Vol. 1, no. 2 (2004): 132.

2 John Naisbitt, Megatrends, New York: Warner Communications Company (1982), 24.

${ }^{3}$ Hamid Keshavarz, "How Credible Is Information on the Web: Reflections on Misinformation and Disinformation," Infopreneurship Journal, Vol. 1, no. 2 (2014): 1 . 
berpendapat bahwa informasi agama Islam di Internet membutuhkan koreksi atau pembetulan ${ }^{4}$

Bahkan tulisan Ahmad "Perkembangan Media Online dan Fenomena Disinformasi: Analisis pada Sejumlah Situs Islam” menyatakan tidak semua website atau portal yang berlabel Islam berisi ajaran atau pandangan Islam, tetapi sebaliknya justru terdapat website atau portal yang berlabel Islam namun bermuatan informasi yang mengaburkan pandangan keislaman, bahkan mengarah kepada sebuah informasi yang dapat menyesatkan pemahaman beragama bahkan dapat menimbulkan konflik antar umat beragama. Ada 4 website yang menurut Ahmad merupakan disinformasi Islam, yaitu: answeringislam.org, aboutislam.com, thequran.com, allahassurance.com. Empat website tersebut berisi informasi yang sangat bertentangan dengan ajaran Islam, bahkan ditengarai dibuat oleh pihak yang anti Islam. $^{5}$

Menjadi penting untuk meneliti kredibilitas informasi melalui internet menjadi sangat penting, karena internet memberikan kemudahan bagi orang yang ingin berbagi maupun mencari informasi. Hal inilah yang mengakibatkan banyaknya website yang aktif, namun tidak mempunyai tim editor yang menyeleksi kredibilitas informasi yang ditampilkan. ${ }^{6}$ Sementara itu Islam telah mempunyai metode penelitian terhadap kredibilitas informasi yang disandarkan kepada Nabi Muhammad saw. yaitu 'ulum al-badits. Dalam 'ulum alhadits mempunyai tiga tingkat terhadap kebenaran informasi, yaitu

${ }^{4}$ Islam A. Nassar, Jamal A. Hayajneh, and KH. Almsafir Mahmoud, "Relation between Social Network and Da'wah to Islam a Case Study on Jordanian Students," International Journal On Islamic Applications In Computer Science And Technology, Vol. 1, no. 1 (2013): 9.

5 Amar Ahmad, "Perkembangan Media Online Dan Fenomena Disinformasi (Analisis Pada Sejumlah Situs Islam)," Jurnal Pekommas Vol. 16, no. 3 (2013): 177.

${ }^{6}$ M. J. Metzger, "Making Sense of Credibility on the Web: Models for Evaluating Online Information and Recommendations for Future Research," Journal Of American Society For Information Science And Technology, 58, no. 13 (2007): 2078. 
sabih (benar), hasan (baik) dan da'if (lemah). ${ }^{7}$ Untuk memeriksa keadaan sebuah informasi terdapat metode yang digunakan, yaitu naqd al-hadits. Menarik untuk mendiskusikan metode naqd al-badits digunakan sebagai metode kritik kredibilitas informasi pada era ini.

\section{Metode Penulisan}

Penulisan ini dengan menggunakan metode deduktif melihat teori kredibilitas informasi pada umumnya, dan mengajukan naqd alhadits sebagai metode kritik kredibilitas informasi yang berasal dari Islam.

\section{Ledakan Informasi}

Everet M. Rogers dalam bukunya "Communication Technology", mengemukakan empat era evolusi komunikasi manusia. Empat era evolusi komunikasi manusia tersebut adalah: (1) Era komunikasi tulisan (the writing era of communication). Era ini dimulai tahun 4000 SM pada waktu bangsa Sumeria melakukan tulis-menulis dari lembaran tanah liat, dan bangsa Cina menemukan cetak buku yang dapat dipindah pada $1041 \mathrm{M}$; (2) Era percetakan (the printing era of communication). Sebelum ditemukannya percetakan, jumlah buku naskah yang ada di Eropa sekitar 1.500. Setelah 50 tahun ditemukannya alat percetakan, jumlah buku diperkirakan lebih dari 9 juta buah. ${ }^{8}$ Era ini dimulai dengan ditemukannya alat percetakan oleh Guttenberg pada tahun 1456 (cetakan pertama Kitab Injil). Kemudian pada tahun 1833, dimulainya sirkulasi media massa Surat Kabar "New York Sun" yang diterbitkan oleh "Penny Press", dan tahun 1839 dimulai adanya fotografi dengan metode praktis dalam surat kabar; (3) Era telekomunikasi (telecommunication era). Dalam era ini, antara lain tercatat Samuel Morse pada tahun 1844 untuk pertama kalinya mengirim pesan secara telegraf.

${ }^{7}$ Fadlan Mohd Othman et al., "The Significance and Application of Takhrij Al-HaditsSciences in Academic Research," Education Research Journal 2, no. 10 (2012): 339.

${ }^{8}$ George Unwin, Philip Soundy U., and David H. Tucker, "History of Publishing," in Encyclopadia Britannica 2008 Ultimate Reference Suite, (Chicago: Encyclopædia Britannica, 2007), th. 
Pada tahun 1976 Alexander Graham Bell untuk pertama kalinya menemukan alat telekomunikasi menggunakan secara telepon. Kemudian, telekomunikasi ini berkembang pesat dengan dilakukannya pengiriman pesan lewat radio dan pada tahun 1920 dimulainya radio siaran yang dilanjutkan dengan penemuan televisi yang didemonstrasikan pada tahun 1933, dan pada 1941 dimulainya tayangan televisi komersial; (4) Era komunikasi interaktif (interactive communication era). Era komunikasi ini dimulai dari ditemukannya komputer yang diberi nama Electronic Numerical Integrator and Computer (ENIAC) pada tahun 1946 di Universitas Pennsylvania. Dalam era ini ditemukan pula transistor pada tahun 1947 dan 1956 ditemukannya pita video. Pada tahun 1957, Rusia meluncurkan satelit sputnik ke luar angkasa. Pada tahun 1979, telah dikembangkan berbagai informasi dalam halaman dan grafis yang dapat dikirimkan dari pusat komputer melalui kabel telefon untuk ditayangkan di televisi rumah. Selanjutnya, berkembang jaringan komunikasi antar komputer di seluruh dunia yang dikenal dengan internet.

Melalui internet dikembangkan teknologi world wide web (www) atau halaman-halaman yang memuat informasi. Menurut internetlivestats.com proyek pembuatan website pertama dimulai pada Agustus 1991. Pada tahun 1992, hanya 10 website dibuat. Perkembangan jumlah website sangat cepat, jumlah website di seluruh dunia mencapai 1 milyar pada bulan September 2014 (interlivestats.com, diunduh pada 12 Mei 2015). ${ }^{9}$ Sedangkan menurut internetworldstats.com jumlah pengguna internet pada pertengahan tahun 2014 mencapai lebih dari 3 milyar user (internetworldstats.com, diunduh pada 12 Mei 2015). Data ini menunjukkan jumlah penyedia informasi dan pengguna informasi di internet semakin meningkat pesat dalam 2 (dua) dasawarsa. ${ }^{10}$

Kehadiran media komunikasi internet, sangat berpengaruh dalam kehidupan masyarakat. Tersedianya informasi di internet semakin besar seiring banyaknya jumlah konsumen informasi.

\footnotetext{
${ }^{9}$ Interlivestats.com, diunduh pada 12 Mei 2015

${ }^{10}$ Interlivestats.com, diunduh pada 12 Mei 2015
} 
Masyarakat cenderung tergantung terhadap keberadaan media internet untuk mengakses informasi. Penggunaan internet dimotivasi dua hal yaitu intrinsik dan ekstrinsik. Motif intrinsik ada dua aspek, yaitu menyenangkan dan mudah digunakan. Sedangkan motif ekstrinsik yaitu internet dirasa sangat bermanfaat bagi penggunanya. ${ }^{11}$

Seiring majunya teknologi informasi, informasi mengalami pertumbuhan yang sangat pesat. Situasi ini oleh sebagian kalangan disebut ledakan informasi atau banjir informasi. Ledakan informasi oleh Briggs disebutkan sebagai kata kiasan yang tidak enak akan sisasisa mesiu dari teknologi informasi. ${ }^{12}$ Sama halnya dengan banjir informasi, ketika banjir informasi, banyak informasi bersifat keruh, sulit untuk mencari informasi yang bersih, jernih, dan terpercaya untuk dapat dipakai. Ledakan informasi telah diprediksi semenjak dikembangkan kertas murah, mesin cetak, ongkos pengiriman yang murah dan tingginya melek huruf. ${ }^{13}$

Permasalahan ledakan informasi di era internet semakin pelik. Pada saat informasi dikuasai penerbit dan media massa, penerbit masih melakukan editorial atas berbagai usulan buku; media massa seperti surat kabar, televisi dan radio masih mengutamakan etika jurnalistik. Era teknologi internet ini informasi tidak dapat dimonopoli. Setiap orang dapat membagikan dengan cepat informasi yang dibuatnya melalui halaman web atau sosial media. Waddington melaporkan hasil penelitian tentang sekaratnya informasi akibat pengaruh informasi yang overload di internet. Statementnya dilatarbelakangi perusahaan korporasi surat kabar di Inggris, Reuter memproduksi 27.000 halaman setiap detik. Peningkatan jumlah informasi ditengarai umumnya disebabkan terdapat peningkatan komunikasi bisnis di perusahaan dengan pelanggan, dan pemasok.

11 Thompson SH Teo, Vivien KG Lim, and Raye YC Lai, "Intrinsic and Extrinsic Motivation in Internet Usage," Omega vol. 27, no. 1 (1999): 25.

12 Asa Briggs, Sejarah Sosial Media, (Jakarta: Yayasan Obor Indonesia, 2000), 22.

13 Alan Bundy, "Drowning in Information, Starved for Knowledge: Information Literacy, Not Technology, Is the Issue" (Victorian Association for Library Automation, 2000), th. 
Ada banyak cara berkomunikasi melalui fax, voice mail, email, internet dan konferensi online, disamping yang konvensional seperti telefon, pertemuan, pos, dan telex. Dua pertiga dari pihak manajemen merasa perlu informasi yang sangat tinggi untuk mendukung pengambilan keputusan dan memenangkan persaingan bisnis, baik individu maupun korporasi. ${ }^{14}$ Melalui media yang sama, pada tahun selanjutnya Griffiths merilis tulisannya yang mengungkapkan bahwa sebagian orang telah kecanduan informasi. Banyak orang sangat membutuhkan informasi yang dan menuntut mendapatkan informasi apa yang mereka cari. ${ }^{15}$ Hal inilah yang menurut Bundy, saat sekarang ini masyarakat di seluruh dunia mengalami tingkat kecemasan yang tinggi terhadap informasi. ${ }^{16}$

Namun informasi yang berada di internet tidak memiliki jaminan hasil pekerjaan editor dan jurnalistik. Di sisi lain masyarakat seringkali kurang memahami seluk-beluk informasi. ${ }^{17}$ Selain itu, menurut Muslimin Muslimin identitas pengunggah informasi di internet bisa jadi asli atau palsu. ${ }^{18}$ Bisa saja semua informasi yang ia masukkan dalam akunnya adalah fiktif atau bisa juga fakta, tidak ada yang tahu kecuali jika kita memang mengenalnya secara dekat. Pada kondisi inilah peluang untuk melakukan "penipuan" atau "pembohongan" terbuka lebar.

\section{Kredibilitas Informasi}

1. Kredibilitas

Kredibilitas secara etimologi dalam bahasa Indonesia berarti perihal yang dapat dipercaya. Sedangkan dalam "Pocket Oxford Dictionary" credible berarti dapat dipercaya. Kredibilitas biasanya oleh

$14 \mathrm{P}$ Waddington, Dying for Information: An Investigation of Information Overload in the Uk and World-Wide, (London: Reuters Business Information, 1996), th.

15 Mark Griffiths, Glued the Screen: A Investigation into Information Addiction Worldwide, (London:: Reuters, 1997).

16 Alan Bundy, "Drowning in Information, Starved for Knowledge: Information Literacy, Not Technology, Is the Issue," 10th VALA Conference, (2000): th.

17 Alan Bundy, "Drowning in Information...".

18 Muslimin "Perkembangan Teknologi Dalam Industri Media," Jurnal Teknik Industri Vol. 12, no. 1 (2011): 64. 
sebagian akademisi dikaitkan erat dengan gagasan Aristoteles tentang retorika. Aristoteles dalam "Rethoric" membagi 3 model dalam persuasi kepada masyarakat yaitu logo, ethos, dan pathos. Logo berkaitan cara komunikator mampu menyampaikan alasan sesuai dengan logika. Ethos, berhubungan dengan kredibilitas, bagaimana komunikan merasa kredibilitas komunikator. Pathos berhubungan dengan emosi, bagaimana melibatkan perasaan komunikan. ${ }^{19}$ Whitehead Jr. menyebutkan ethos gagasan Aristoteles berbicara tentang kredibilitas sumber. ${ }^{20}$

Plato merujuk Socrates dalam Brahnam berpendapat bahwa tubuh dan ucapan tidak dapat dipisahkan. Tulisan tidak memiliki ethos, karena komunikator tidak ada. Sebuah tulisan dianggap mempunyai banyak interpretasi. Setiap wacana dapat diinterpretasikan ke mana-mana oleh pembaca, tanpa pandang bulu apakah pembaca yang mempunyai pemahaman atau tidak dengan topik yang ditulis. Komunikator tidak bisa mengendalikan kepada siapa harus disampaikan dan kepada siapa seharusnya tidak disampaikan. Sebuah tulisan yang bersifat menyalahkan atau menyerang secara tidak adil, dianggap tidak bisa mempertahankan dirinya sendiri tanpa kehadiran komunikator (penulis). ${ }^{21}$

Menurut Socrates sebuah tulisan sulit diklaim kredibilitasnya, karena dianggap melanggar dimensi good sense, excellence dan good will. Kritikan Socrates yang cukup telak terhadap kredibilitas tulisan adalah kurangnya good sense (berfikiran sehat); karena tidak mampu mempertahankan diri saat diserang, mengulang kata-kata yang sama tanpa henti dan variasi, gagal dalam bidang pertanyaan, tidak memiliki persepsi, dan tidak dapat menyesuaikan bahasa dan gaya penyampaian untuk mengakomodasi perbedaan psikologis pada komunikan ketika bertemu. Selanjutnya, sebuah tulisan dianggap

${ }^{19}$ Miriam J. Metzger and Andrew J. Flanagin, "Credibility and Trust of Information in Online Environments: The Use of Cognitive Heuristics, ," Journal Of Pragmatics, Vol. 59(2013): 211.

20 Jack L Whitehead Jr, "Factors of Source Credibility," Quarterly Journal Of Speech 54, no. 1 (1968): 59.

21 Sheryl Brahnam, "Building Character..." 15. 
tidak mempunyai good will (niat yang baik), bagaimana mungkin tujuan tulisan untuk mensejahterakan pikiran pembaca jika tidak mau berinteraksi? Sehingga tulisan dianggap tidak berbudi luhur karena menipu. Tulisan diibaratkan lukisan, gambar berpura-pura menjadi apa yang bukan sesungguhnya. Tulisan dianggap seperti pidato hidup.

Berbeda dengan pendahulunya Socrates dan Plato, para pengikut Aristoteles menganggap konsep ethos dapat diterapkan di dalam teks. Karakter seorang penulis terungkap melalui gaya tulisannya, apakah hasil rancangan atau merupakan kegagalan, dan penulis yang meyakinkan adalah yang berhasil menunjukkan kredibilitas tulisan meliputi good sense, excellent dan good will. Paham ini dipakai hampir 2.500 tahun. $^{22}$ Setelah perang dunia kedua, dimensi kredibilitas berubah menjadi expertness (keahlian), trustwortbiness (dapat dipercaya) dan bertujuan ke pembaca. ${ }^{23}$

Proses transfer ethos sering diperkuat, dengan kebiasaan pada anak-anak menganggap bahwa buku teks memiliki kewenangan yang besar, dengan tanpa kritik. Berbeda dengan orang dewasa yang membutuhkan proses promosi untuk transfer ethos. Seorang penulis yang mengundang kawan-kawan untuk memberikan kritik atas tulisannya adalah bentuk membangun reputasi ethos. ${ }^{24}$

Kredibilitas menurut Rakhmat adalah persepsi komunikan terhadap sifat-sifat komunikator, bukan inherent dalam diri komunikator $^{25}$. Ada dua hal penting dalam kredibilitas menurut Rakhmat, yaitu persepsi komunikan dan sifat-sifat komunikator. Persepsi komunikan merupakan tanggapan komunikan terhadap komunikator. Sedangkan sifat-sifat komunikator dijabarkan melalui komponen-komponen kredibilitas, yaitu keahlian dan kepercayaan. ${ }^{26}$ Keahlian merupakan kesan yang dibentuk komunikan tentang

22 Sheryl Brahnam, "Building Character..." 16.

${ }^{23}$ James C McCroskey and Thomas J Young, "Ethos and Credibility: The Construct and Its Measurement after Three Decades," 25.

24 Sheryl Brahnam, "Building Character..." 17.

25 Jalaluddin Rakhmat, Psikologi Komunikasi... 257.

26 Jalaluddin Rakhmat, Psikologi Komunikasi... 260. 
kemampuan komunikator dalam hal topik yang dibicarakan. Komunikator yang dinilai tinggi pada keahlian dianggap sebagai cerdas, mampu, ahli, tahu banyak, berpengalaman, atau terlatih. Kepercayaan adalah kesan komunikan tentang komunikator yang berkaitan dengan wataknya. Apakah komunikator dinilai jujur, tulus, bermoral, adil, sopan dan etis? Atau apakah ia dinilai tidak jujur, lancung, sikap menipu, tidak adil, dan tidak etis?.

Koehler, Annatol, dan Applbaum menambahkan empat komponen kredibilitas komunikator: (1) dinamisme yaitu bergairah, semangat, aktif, tegas, dan berani; (2) sosiabilitas yaitu periang dan senang bergaul; (3) koorientasi berarti mewakili nilai-nilai komunikan; dan (4) karisma untuk menunjukkan sifat luas biasa yang dimiliki komunikator yang menarik dan mengendalikan komunikan seperti magnet menarik benda-benda di sekitarnya. ${ }^{27}$

Dari beberapa penjelasan kredibilitas di atas, baik dari Aristoteles yang klasik dan Koehler yang modern lebih di dominasi kredibilitas pada sosok komunikator yang melakukan tatap muka terhadap komunikan. Menurut Rieh dan Danielson metode pemeriksaan kredibilitas telah menjangkau beberapa bidang keilmuan, mulai dari komunikasi, informasi ilmiah, psikologi, marketing, manajemen pengetahuan, dan interaksi manusia dengan komputer. Tiap bidang keilmuan dalam melakukan pemeriksaan kredibilitas tentu berbeda pendekatan, tujuan dan asumsi. ${ }^{28}$

\section{Informasi}

Informasi secara etimologi dalam Software Kamus Besar Bahasa Indonesia diartikan penerangan; pemberitahuan; kabar atau berita tentang sesuatu; keseluruhan makna yang menunjang amanat yang terlihat dulu bagian-bagian amanat itu. Dalam Software Kamus Oxford, informasi diartikan sebagai something told (suatu perkataan); knowledge (pengetahuan); item of knowledge (bagian dari pengetahuan); news (berita), charge or complaint lodged with a court (keluhan yang diajukan

27 Jalaluddin Rakhmat, Psikologi Komunikasi... 260.

${ }^{28}$ Soo Young Rieh and David R Danielson, "Credibility: A Multidisciplinary Framework," Annual Review Of Information Science And Technology 41, no. 1 (2007): 308. 
di pengadilan). Dalam pengetahuan populer, term information digunakan untuk menunjukkan fakta dan opini yang disajikan atau diterima. Seseorang bisa mendapat informasi secara langsung dari sesama, dari media massa atau dari berbagai fenomena yang ada di sekelilingnya dan bisa diamati.

Menurut Liew informasi adalah pesan yang mengandung makna, implikasi, atau masukan untuk keputusan dan aksi. Informasi dapat berupa kondisi saat ini dan kondisi masa lalu (sejarah). Tujuan dari informasi untuk membantu dalam membuat keputusan dan/atau memecahkan masalah atau membaca peluang. ${ }^{29}$

Informasi merupakan salah satu fungsi dari empat fungsi komunikasi. Menurut Thayer (1968), keempat fungsi komunikasi adalah fungsi instruksi dan komando, fungsi mempengaruhi dan persuasif, fungsi integrasi dan fungsi informasi. ${ }^{30}$

Karakter informasi sebagai pengetahuan, menunjukkan informasi mempunyai daya dan memiliki nilai, serta merupakan kekayaan yang bisa dimiliki atau tidak dimiliki seseorang. Maka ada sebagian orang yang disebut kaya informasi, dan ada juga yang disebut miskin informasi. Kondisi ini disebabkan distribusi informasi yang tidak merata. ${ }^{31}$

Kesenjangan informasi (information gap) banyak memotivasi pelaku media massa untuk menyajikan informasi dan memperjuangkannya sebagai tindakan pembangunan. Di Indonesia, para praktisi media menjadikan pemerataan informasi sebagai alasan pendirian institusi media, demikian juga halnya dengan kebebasan pers juga dinisbahkan pada hipotesis kesenjangan informasi.

3. Disinformasi dan Misinformasi

Informasi yang menyesatkan mungkin terjadi karena melalui kesalahan atau ketidaktahuan, atau karena terjadi karena ada unsur

29 Anthony Liew, "Understanding Data, Information, Knowledge and Their Inter-Relationships," Journal Of Knowledge Management Practice, Vol. 8, no. 2 (2007): th.

30 Tata Taufik, Etika Komunikasi Islam Kritik Terbadap Teori Komunikasi Barat (Bandung: Sahifa, 2008), 30.

31 Tata Taufik, Etika Komunikasi Islam... 31. 
penipuan. Informasi yang salah disebut disinformasi. Fetzer mendefinisikan disinformasi distribusi, pernyataan, atau penyebaran informasi palsu, salah, untuk sengaja menyesatkan atau usaha untuk bertujuan menyesatkan, menipu, atau membingungkan. ${ }^{32}$

Disinformasi terjadi karena pelaku sengaja memberikan informasi yang menarik atau menggiurkan bagi para korbannya. Biasanya terjadinya disinformasi ini terjadi pada situs jual-beli dengan menawarkan harga sangat rendah dibandingkan harga pasaran. Selain itu disinformasi biasanya juga terjadi pada situs investasi online dengan menawarkan keuntungan yang sangat besar tanpa usaha yang besar. Situs investasi jarang sekali memuat informasi resiko-resiko yang terjadi bila bergabung. Disinformasi juga terjadi ketika quick count pemilihan presiden (pilpres) kemarin. Salah satu pasangan capres dan cawapres memuat quick count yang salah untuk mengacaukan hasil pilpres.

Misinformasi adalah informasi yang salah atau tidak sengaja salah, namun tidak selalu muncul untuk menipu pengguna. Calvert menggunakan istilah misinformasi untuk menggambarkan informasi yang tidak sesuai dengan pola kebenaran normatif, bahkan misinformasi dapat berupa informasi yang lengkap, namun dari sisi penanggalan yang membingungkan, atau pengetahuan yang tidak diterima secara umum. ${ }^{33}$

Fitzgerald mengidentifikasi beberapa jenis misinformasi, yaitu informasi yang tidak lengkap, pranks (senda gurau), kontradiksi, outof-date informasi, penerjemahan data yang kurang tepat, tidak kompatibel software, kesalahan faktual, bias informasi dan kesalahan ilmiah. Tiga masalah yang berbeda yang menyebabkan misinformasi dan disinformasi di internet: sifat struktur internet: seperti data dapat berubah, arsitektur internet: seperti kurangnya otoritas pusat, dan penyebab klasik misinformasi. Dia menghitung "masalah lama dalam bentuk baru" sebagai penyebab paling penting dari misinformasi. Ini adalah kesalahan manusia, misconduct (tidak terpuji), penghapusan

\footnotetext{
32 Hamid Keshavarz, "How Credible Is Information..." 4.

${ }^{33}$ Hamid Keshavarz, "How Credible Is Information..." 3-4.
} 
informasi dari konteksnya, kurangnya persebaran informasi, dan bias informasi. ${ }^{34}$

Sedangkan penyebab disinformasi sangat berbeda. Hal ini berkaitan dengan niat pelaku untuk memalsukan informasi. Niat disinformasi biasanya terkait dengan politik dan komersial. Disinformasi diproduksi dan disebarkan secara sengaja untuk menyesatkan masyarakat ${ }^{35}$

\section{Kredibilitas Informasi}

Sebagian besar akademisi berpendapat kredibilitas merupakan persepsi kualitas yang terdiri dari beberapa dimensi, yaitu kepercayaan dan keahlian. ${ }^{36}$ Kepercayaan didapat dari kebaikan dan moralitas yang baik, seperti mempunyai maksud yang baik, jujur dan obyektif. Sedangkan eksper dapat dilihat dari pengetahuan yang luas, berpengalaman dan kompetensi. Menurut Rieh dan Danielson berdasarkan sejarah, kredibilitas informasi biasanya dilakukan oleh profesional berpengetahuan, seperti editor, reviewer, percetakan, jurnalis, dan pustakawan. ${ }^{37}$

Informasi yang dipercaya menurut Wathen dan Burkell berasal dari interaksi sumber, informasi dan penerima. Karakteristik sumber berupa keahlian dan dapat dipercaya. Karakteristik informasi meliputi logis, konsisten, dan berkualitas. Sedangkan karakteristik penerima yang berlatarbelakang budaya dan keyakinan yang sama dengan sumber. Interaksi ketiga faktor tersebut sangat dipengaruhi oleh ide Socrates dan Aristoteles tentang kredibilitas. ${ }^{38}$

Aristoteles dalam bukunya De Arte Rhetorica sebagaimana dikutip Rakhmat menjelaskan betapa pentingnya peranan taxis dalam

34 Mary Ann Fitzgerald, "Misinformation on the Internet: Applying Evaluation Skills to Online Information," Teacher Librarian 24, no. 3 (1997): 11.

35 Paul S Piper, Better Read That Again: Web Hoaxes and Misinformation(Learned Information, 2001), 1.

${ }^{36}$ Shawn Tseng and B.J Fogg, "Credibility and Computing Technology," Communication af The ACM, Vol. 42, no. No. 5 (1999): 40.

37 Soo Young Rieh and David R Danielson, "Credibility: A Multidisciplinary Framework," 307.

${ }^{38}$ C. N. Wathen and J. Burkell, "Believe It or Not: Factors Influencing Credibility on the Web.," Journal of the American society for information science and technology, 53, no. 2 (2002): 134. 
memperkuat efek pesan persuasif. Taxis adalah rangkaian penyusunan informasi. Aristoteles menyarankan agar setiap penyusunan informasi dirangkai menurut urutan: pengantar, pernyataan, argumen, dan kesimpulan. ${ }^{39}$

Rakhmat mengutip "Retorika" Aristoteles mengenal enam macam organisasi informasi: deduktif, induktif, kronologis, logis, spasial dan topikal. Deduktif dimulai dengan menyatakan dulu gagasan utama, kemudian memperjelasnya dengan keterangan penunjang, penyimpulan dan bukti. Induktif mengemukakan perincian-perincian dan kemudian menarik kesimpulan. Kronologis, informasi disusun berdasarkan urutan waktu terjadinya peristiwa. Logis, informasi disusun berdasarkan sebab akibat atau akibat ke sebab. Spasial, informasi disusun berdasarkan tempat. Topikal, informasi disusun berdasarkan topik pembicaraan: klasifikasi dari yang penting kepada yang kurang penting, dari yang mudah kepada yang sukar, dari yang dikenal kepada yang asing. ${ }^{40}$

Pengorganisasian informasi yang tersusun menurut Beighley mempunyai efek lebih mudah dimengerti daripada pesan yang tidak tersusun dengan baik. ${ }^{41}$ Sedangkan menurut Darnell perubahan sikap pembaca sangat dipengaruhi oleh informasi yang tersusun dengan baik. ${ }^{42}$

Menurut Dahlan dkk kredibilitas isi informasi, merupakan faktor yang paling sulit untuk diukur. Namun ini merupakan salah satu yang harus diperhatikan karena menyangkut kebenaran. Untuk menilai secara obyektif kredibilitas isi informasi, orang harus memiliki pemahaman yang cukup tentang informasi itu sendiri. Tapi begitu orang memiliki pemahaman tentang hal itu mereka mungkin tidak akan mencari informasi dari internet lagi. ${ }^{43}$

39 Jalaluddin Rakhmat, Psikologi Komunikasi... 294.

40 Jalaluddin Rakhmat, Psikologi Komunikasi... 295.

41 Jalaluddin Rakhmat, Psikologi Komunikasi... 294-95.

42 Jalaluddin Rakhmat, Psikologi Komunikasi... 294-95.

43 Ahmad Dahlan et al., "Ranking the Online Documents Based on Relative Credibility Measures," Journal Of Ict Research And Applications 3, no. 1 (2009): 20. 
Standler memaparkan 3 metode mengevaluasi kredibilitas informasi, yaitu: (1) peer review, (2) legalitas penulis, (3) gaya tulisan. Peer review biasa digunakan oleh penerbit buku yang mempunyai reputasi bagus dan penerbitan jurnal. Kriteria kredibel diserahkan oleh pembaca yang ditunjuk penerbit. Penulis yang dipercaya merupakan penulis yang berasal dari level akademisi, lebih tinggi levelnya lebih dipercayai, seperti Profesor atau Doktor. Gaya tulisan mencakup: kutipan, kesalahan ketik, struktur bahasa, konsisten, tidak sindiran tajam, menyerang orang lain, penanggalan artikel. ${ }^{44}$ Namun Standler dalam kesimpulannya mengemukakan

Pembaca dapat, dan harus, berkemauan sendiri mencari kredibilitas informasi, bukan membabi buta mengandalkan peer review. Sebuah artikel yang baik, itu baik karena keterampilan, wawasan, ketekunan, atau kreativitas penulis, bukan karena beberapa ahli atau otoritas disahkan itu. Kesimpulan Sebuah hanya sebagai baik sebagai alasan untuk percaya kesimpulan itu. Kesimpulan Sebuah menyatakan tanpa alasan, atau dengan alasan yang tidak memadai, tidak berharga. Ini adalah tugas pembaca untuk memutuskan apakah alasan yang memadai dan meyakinkan. ${ }^{45}$

5. Kredibilitas Media

Hungbo menyatakan bahwa kredibilitas informasi terintegrasi dengan media. Media bertanggung jawab terhadap informasi yang dimuatnya dan dapat menilai sendiri apakah kredibel atau tidak. Media yang kredibel dapat dipastikan melakukan seleksi informasi yang cukup ketat. Oleh karena itu untuk menilai kredibilitas media, terlebih dahulu menilai kredibilitas informasi yang dimuatnya. ${ }^{46}$

Ketika media massa muncul dan berkembang hingga saat ini, seperti koran, televisi dan media online, kredibilitas tidak hanya melihat pada informan dan informasinya, melainkan juga pada media yang memuatnya. Hasil penelitian Kiousis mengungkapkan bahwa

44 Ronald B Standler, "Evaluating Credibility of Information on the Internet," (2004), www.rbs0.com/credible.pdf

45 Ronald B Standler. 13.

46 Jendele Hungbo, "Credible News Measures: A Medium's Integrity," Nebula, vol. 4, no. 1 (2007): 282. 
pada umumnya masyarakat meragukan kebenaran berita yang dimuat 3 media, yaitu koran, televisi dan media online. Namun masyarakat menilai bahwa koran dianggap media paling kredibel dibandingkan dengan yang lainnya. Sedangkan yang kedua ditempati oleh berita online. Media televisi menempati urutan ketiga. ${ }^{47}$

Persepsi user terhadap kredibilitas dari berita online pada umumnya positif. Orang-orang mempercayai internet sebagai sumber berita sebagaimana media lain. Oleh karena itu, Internet adalah sumber daya yang paling penting bagi berita. Di antara situs berita online, blog dianggap kurang dapat dipercaya dari situs berita konvensional. Sebuah survei tahun 2005 menunjukkan bahwa, bahkan di antara orang-orang muda, blog dipandang kurang dapat dipercaya daripada situs berita tradisional. Namun, dalam kajian akademis, persepsi pengguna bukan menjadi tolok ukur utama untuk mengetahui apakah sebuah website dapat dipercaya atau tidak. ${ }^{48}$

Hungbo menekankan untuk pemberitaan yang kredibel berada pada tanggung jawab dua pihak, yaitu manajemen media dan orangorang di balik media, meliputi wartawan, editor, sub-editor, manajer dan pemilik media. ${ }^{49}$

\section{Kredibilitas Informasi dalam Islam}

1. Kredibilitas dalam Islam

Kredibilitas berarti dapat dipercaya, sedangkan dalam bahasa Arab kata yang bermakna kredibilitas, yaitu al-amin dan al-siqah. Julukan al-amin disematkan kepada Nabi Muhammad saw. Pemberian gelar al-amin (dapat dipercaya) diberikan oleh kaum Quraisy kepada akhlak Nabi Muhammad saw. yang telah menyelesaikan dengan memuaskan beberapa kabilah yang bertikai dalam peletakan batu hajar aswad di kabah. Selain itu penyematan gelar al-amin kepada Nabi Muhammad karena beliau memiliki sifat siddiq (jujur), amanah (dapat

${ }^{47}$ Spiro Kiousis, "Public Trust or Mistrust? Perceptions of Media Credibility in the Information Age," Mass Communication And Society Vol. 4, no. No. 4 (2001): 381.

48 Carlos Castillo, Marcelo Mendoza, and Barbara Poblete, "Information Credibility on Twitter," in WWW2011, (Hyderabad, India: IW3C2, 2011), 675.

49 Jendele Hungbo, "Credible News Measures..." 283. 
dipercaya), fathanah (pandai) dan tablig (menyampaikan). Penyematan gelar al-amin dalam Islam hanya diberikan kepada Rasulullah. Sesudah itu, sepengetahuan penulis belum ada sababat ataupun ulama yang mendapat gelar al-amin.

al-Siqah juga berarti dapat dipercaya atau dianggap dapat dipercaya, berasal dari kata wasaqa secara bahasa berarti percaya kepadanya. Kata al-siqah biasa digunakan dalam 'ulum al-hadits yang berarti seseorang yang terkumpul padanya 'adalah (moral). dhabit (daya ingat yang kuat) dan itqan (kompetensi). Menurut al-Dzahaby 'adalah merupakan persaksian keadaan (kualitas) rawi, kemudian siqah dalam dhabit dan itqan penggabungan keduanya dipahami oleh orang banyak sebagai hafizh. ${ }^{50}$

al-'Adalah berarti seimbang, dalam kitab "Lisan al-Arab" al adalabberarti tegaknya hati yang lurus, dan tertolaknya kezaliman dan tidak tampak darinya keraguan. Menurut istilah 'adalah adanya tabiat membawa atas ketetapan taqwa dan muruah. Maksud dari taqwa adalah jauh dari dosa syirik, fasik, dan bidah. Sedangkan muruah adalah perilaku yang baik secara sosial dan agama, seperti dermawan, akhlak yang bagus dan jauh dari hal-hal kotor dan aib (cela) secara sosial. Sedangkan menurut Ibn al-Shalah rincian 'adalah adalah muslim, balig, berakal, terhindar dari fasik, dan hal-hal yang merusak muru'ah. Selain itu kriteria 'adalah adalah bukan peminum dan pembohong 51

Dhabit berarti menguasai secara bahasa berarti keharusan memenjarakan sesuatu. Sedangkan pengertian dhabit adalah kemampuan rawi memelihara hadits baik melalui hafalan (dhabit alshadr) maupun catatan (dhabit kitab) yaitu mampu meriwayatkan hadits itu sebagaimana diterimanya. Menurut al-'Abd al-Lathif menyebutkan bahwa penelitian kedhabit-an mencakup 3 (tiga) hal, yaitu: penelitian kesatupaduan dhabit shadr dan dhabit kitab; penelitian secara khusus pada dhabit shadr yang mencakup: (1) buruknya hafalan

50 'Abd Rahman al-Khamîsî, Mu'jam 'UlûM Al-Hâdis an-Nabawî, Jeddah: Darul Andalus, 1419 H.), 79-80.

${ }^{51}$ M. Mustafa al-A'zamî, Studies in Hadith Methodology and Literature(Riyadh: The Other Press, 1977), 58. 
rawi (2) banyak mukhalafah (perdebatan), (3) banyaknya waham (prasangka), (4) banyak lalai, (5) banyak kesalahan; dan penelitian khusus terhadap dhabit kitab. ${ }^{52}$

Dengan demikian kredibilitas dalam Islam merujuk pada kata siqah, yang terdiri dari tiga aspek, yaitu 'adalah. dabit. dan itqan. Apabila dijabarkan unsur-unsur siqah yaitu: muslim, balig, berakal, tidak fasik, menjaga kehormatan secara adat (budaya), mempunyai daya ingat yang tinggi, catatan yang baik dan kompeten.

2. Informasi dalam Islam

Sinonim dalam bahasa Arab yang bermakna informasi ada beberapa kata, yaitu nabaa, hadits. khabar. balagh. dan ilam. Nabaa secara bahasa berarti sesuatu yang tinggi, berita, dan bersuara pelan. Sedangkan menurut istilah, nabaa diartikan sebagai "berita yang mengandung faedah yang sangat besar yang akan menghasilkan ilmu dan tidak adanya keraguan di dalamnya. ${ }^{53}$

Al-Quran menggunakan kata nabaa sebanyak 12 kali dengan makna berita dan kisah. ${ }^{54}$ Salah satunya yaitu al-Quran surat alHujurat ayat 6:

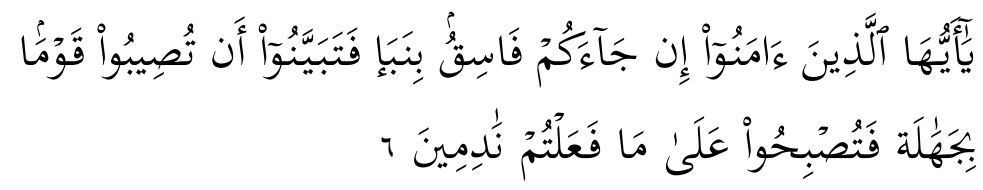

Hai orang-orang yang beriman, jika datang kepadamu orang fasik membawa suatu berita, maka periksalah (kebenarannya) dengan teliti, agar kamu tidak menimpakan suatu musibah kepada suatu kaum tanpa mengetahui keadaannya yang menyebabkan kamu menyesal atas perbuatanmu itu".

52 M. Abdurrahman and Elan Sumarna, Metode Kritik Hadits(Bandung: PT. Remaja Rosdakarya, 2013), 133.

53 Râgib al-Isfhânî, Mufradât Alfầ̆h Al-Qurân (Damaskus: Dâr al-Qalam, 425 H.), 788.

54 1. (QS. 5:27), 2. (QS. 7:175), 3. (QS. 9:70), 4. (QS. 10:71), 5. (QS. 14:9), 6. (QS. 26:69), 7. (QS. 38:21), 8. (QS. 38:67), 9. (QS. 64:5), 10. (QS. 6:34), 11. (QS. 6:67), 12. (QS. 28:3) 
Dari ayat di atas, maka diketahui ada dua aspek yang harus diperiksa dalam meneliti kredibilitas informasi, yaitu pembawa berita dan isi berita

Kata hadits dalam bahasa Arab mengandung berarti tiga arti, yaitu jadid (baru), qarib (dekat), dan khabar (warta atau berita). Pengertian hadits adalah "segala ucapan, perbuatan dan keadaan Nabi Muhammad saw". 55 Sedangkan khabar berarti kabar berita, namun sebagian ulama berpendapat bahwa khabar sama dengan hadis yang disandarkan kepada Nabi Muhammad saw. ${ }^{56}$ Balagh berarti pengumuman/pemberitahuan, ${ }^{57}$ I'lam biasa diartikan sebagai media massa.

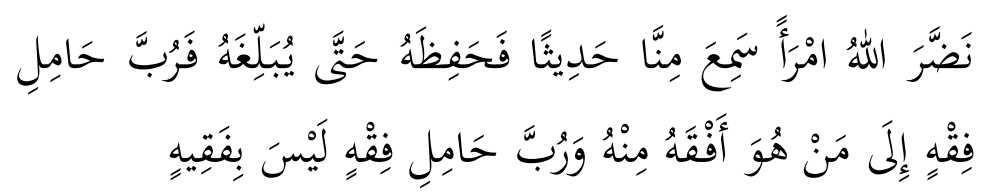

"Semoga Allah memperindah orang yang mendengar hadits dariku lalu menghafal dan menyampaikannya kepada orang lain, berapa banyak orang menyampaikan ilmu kepada orang yang lebih berilmu, dan berapa banyak pembawa ilmu yang tidak berilmu." (Abu Dawnd No. 3175, Software lidwa)

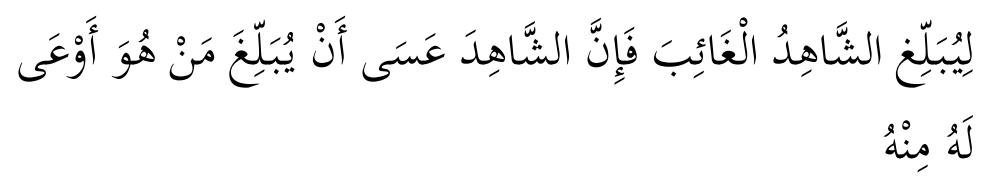

(Maka) hendaklah yang hadir menyampaikan kepada yang tidak hadir, karena orang yang hadir semoga dapat menyampaikan kepada orang yang lebih paham darinya". (Bukhary - 65, software lidwa)

$$
\text { بَلِّغُوا عَنِيّ وَلَوْ آيَةً }
$$

Sampaikanlah dariku walaupun banya satu ayat (Tirmi氵y - 2593, Software Lidwa).

55 M. Hasbi Ash-Shiddieqy, Sejarah \& Pengantar Ilmu Hadits (Semarang: Pustaka Rizki Putra, 2009), 3-6.

56 Sohari Sahrani, Ulumul Hadits (Bogor: Ghalia Indonesia, 2010), 12.

${ }^{57}$ Ibn al-Manz $\square$ r, Lisân Al-' Arab, vol. Juz 8(Beirut: Dar Sadr, 1300 H.), 419. 
Informasi jika diartikan knowledge, bisa berarti bahwa informasi menurut konsep Islam adalah ajaran Islam itu sendiri. Konsep pengetahuan dalam Islam bukan hanya sekedar tahu (knowing) tapi pengamalan (practice). Jadi tugas utama manusia terhadap pengetahuan adalah mengamalkannya. ${ }^{58}$

3. Kredibilitas (keshahib-an) Informasi dalam Islam

Islam sudah mempunyai metode penyeleksian informasi yang secara khusus disandarkan pada Nabi, yaitu 'ulum al-hadits. Ilmu ini muncul dilatarbelakangi banyaknya bermunculan hadits-hadits palsu setelah Ali bin Abi Thalib wafat. Kesadaran untuk melakukan seleksi terhadap kesahihan hadits baru muncul pada abad ke-3 H. dilakukan oleh Ishaq Ibn Rahawaih, kemudian disempurnakan oleh Imam alBukhary dan diikuti oleh Imam Muslim. Kemudian disusul oleh imam lain yang mengikuti jejaknya, seperti Abu Dawud (Sunan Abi Dawud), at-Tirmizy (Sunan Tirmizy) dan an-Nasaiy (Sunan anNasaiy). ${ }^{59}$

Faktor-faktor informasi dianggap kredibel diantaranya adalah informasi bersifat kekinian, akurat, obyektif, cakupan yang spesifik dan memuat rujukan sumber. ${ }^{60}$ Meminjam 'ulum al-badits. informasi yang kredibel disebut shahih (benar). Kesahihan informasi dalam Islam, dilihat dari dua hal, kualitas dan kuantitas. Informasi yang kredibel dari aspek kualitas, maka dilihat 3 aspek, yaitu sanad bersambung, rawi yang siqah dan matan. ${ }^{61}$

Sanad yang diterima dalam ulum al-hadits merupakan jalur periwayatan (sumber) yang bersambung sampai pada Nabi. Sebuah informasi dianggap kredibel, apabila mencantumkan sumber informasi yang didapat dari awal sampai akhir. ${ }^{62}$ Sanad dalam tradisi akademik sekarang mirip dengan kutipan atau referensi. Sebuah

58 Tata Taufik, Etika Komunikasi Islam... 219.

${ }^{59}$ M. Hasbi Ash-Shiddieqy, Sejarah \& Pengantar Ilmu Hadits... 50-61.

60 Ahmad Dahlan et al., "Ranking the Online... ," 20.

${ }^{61}$ Fatchur Rahman, Ikbtishar Mushthalabul-Hadits, (Bandung: PT. Al-Ma'arif, 1970), 95.

${ }^{62}$ Fatchur Rahman, Ikbtishar Mushthalabul-Hadits, , 95. 
tulisan yang dianggap dapat dipercaya, salah satunya adalah mencantumkan sumber dari mana penulis mendapatkan informasi.

Rawi adalah orang yang menceritakan hadits. Rawi informasi yang siqah (kredibel) merupakan orang yang terdiri dari tiga aspek, yaitu 'adalah. dhabit. dan itqan. Apabila dijabarkan unsur-unsur siqah yaitu: muslim, balig, berakal, tidak fasik, menjaga kehormatan secara adat (budaya), mempunyai daya ingat yang tinggi, catatan yang baik dan kompeten.

Menurut matan badits yang kredibel adalah: ${ }^{63}$ (a) Ungkapannya tidak dangkal, sebab ucapan dangkal tidak akan keluar dari orang yang mempunyai apresiasi sastra tinggi, (b) tidak menyalahi orang yang luas pandangannya, (c) tidak menyimpang dari kaidah umum dan akhlak, (d) tidak menyalahi perasaan dan pengamatan, (e) tidak menyalahi cendekiawan dalam bidang kedokteran dan filsafat, (f) tidak bertentangan dengan akal, (g) tidak menyalahi sunah Allah mengenai alam semesta dan kehidupan manusia, (h) tidak bertentangan dengan al-Quran dan sunnah serta ijma' (kesepakatan) ulama, (i) tidak bertentangan dengan sejarah Nabi yang telah masybur diketahui umum, (j) tidak menyerupai mazhab rawi yang tampak ingin benar sendiri, (k) tidak meriwayatkan kejadian yang dapat disaksikan orang banyak, (l) tidak menguraikan riwayat yang isinya menonjolkan kepentingan pribadi, (m) tidak mengandung uraian yang isinya membesar-besarkan terhadap perbuatan dosa kecil.

Kemudian, hadis hasan menurut ialah hadis yang sanadnya bersambung, rawinya 'adil. tidak terdapat syadz (kejanggalan), tidak ada 'illat (cacat). rawinya kurang dhabit. Sedangkan hadis dha'if menurut an-Nawawi adalah hadis yang di dalamnya tidak terdapat syarat-syarat hadis sahih dan syarat hadis hasan. Dengan demikian suatu hadis dikategorikan dha'if apabila satu syarat saja hilang. Seperti sanad tidak bersambung, rawi tidak 'adil. tidak dhabit. terdapat syadz, (kejanggalan) dan illat (cacat). ${ }^{64}$

${ }^{63}$ M. Abdurrahman and Elan Sumarna, Metode Kritik Hadits, 100-01.

${ }^{64}$ Sohari Sahrani, Ulumul Hadits 114. 
Kredibilitas informasi dari sisi kuantitas dalam ulum al-hadits. adalah melihat kuantitas jalur periwayatan berbeda yang berkualitas (thabaqat). Sebuah informasi dianggap kredibel dari aspek kuantitas, jika jumlah jalur periwayatan dianggap tidak dapat bersepakat berbohong. Sebagian ulama berpendapat jika jalur periwayatan berjumlah minimal 4 orang, ada yang menetapkan 5 orang, 10 orang, 20 orang, 40 orang, dan 70 orang, maka informasi itu dianggap kredibel atau dalam istilah ilmu hadits dinamakan "mutawatir". Sedangkan kuantitas jalur periwayatan hadits di bawah mutawatir disebut hadits ahad. ${ }^{65}$

\section{Naqd al-Hadits}

Secara bahasa al-naqd mempunyai pengertian sama dengan altanqad yaitu meneliti seksama, menyatakan secara khusus yang asli dan menyingkirkan yang palsu darinya. Naqd oleh sebagian kalangan diartikan sebagai kritik. Dan kata naqd digunakan oleh sebagian ulama badits awal di abad kedua dengan makna kritik. Metode naqd hadits pada masa Nabi saw, yaitu melakukan verifikasi atas informasi yang disandarkan kepada Nabi dengan menanyakan langsung kebenarannya kepada Nabi. ${ }^{66}$

Menurut Ash-Shiddieqy kaidah naqd al-badits dibagi atas dua macam $^{67}$, yaitu:

1. An-Naqd al-Kharijiyyun (kritik sanad hadits)

Pada kaidah al-naqd al-kharijizyun ini membahas tentang cara-cara periwayatan hadits. sahnya periwayatan. keadaan rawi, dan kadar kepercayaan kepada mereka. Kritik pada umumnya berkisar di sekitar persoalan, yaitu ketersambungan sanad dan kesiqahan rawi.

Kritik terhadap sanad merupakan penyelidikan terhadap kejujuran rawi menyampaikan sumber hadits didapat. Langkah pertama dalam melakukan penelitian hadits adalah melihat ittisa alsanad (bersambungnya sanad) sampai pada Rasulullah saw.. Ada

${ }^{65}$ Saifuddin Zuhri, "Predikat Hadis Dari Segi Jumlah Riwayat Dan Sikap Para Ulama Terhadap Hadis Ahad "Subuf, vol. 20, no. 1 (2008): 55-57.

${ }^{66}$ M. Mustafa al-A'zamî, Studies in Hadith Methodology and Literature, 47-48.

${ }^{67}$ M. Hasbi Ash-Shiddieqy, Sejarah \& Pengantar Ilmu Hadits... 279-80. 
beberapa langkah untuk melihat ittisa al-sanad, yaitu: mencatat semua rawi dalam sanad yang akan diteliti, mempelajari masa hidup masingmasing rawi, mempelajari sigat tahammul wa al-'ada yaitu bentuk lafal ketika menerima atau mengajarkan hadits. meneliti guru dan murid. ${ }^{68}$

Penelitian terhadap kesiqahan rawi dengan metode jarb wa ta'dil. Menurut Ibn Atsir al-Jazari dalam kitabnya 'Jami' al- Ushul fi Abadis al-Rasul" menjelaskan Jarb adalah suatu sifat di mana rawi dan persaksiannya dianggap jatuh dan batal dalam pengamalannya, sedangkan ta'dil adalah sifat di mana rawi dan persaksiannya diterima. ${ }^{69}$ Memahami ilmu Jarh wa ta'dil berarti telah memahami bagaimana seorang rawi itu diterima atau ditolak periwayatannya. Dalam ilmu Jarb wa ta'dil dibahas pula kaidah-kaidah yang berkaitan dengan Jarh wa ta'dil dan syarat-syarat yang harus dimiliki oleh Jarib dan mu'addilitu sendiri sehingga penta'dilan dan pentajrib dapat diterima atau ditolak. Metode jarb dan ta'dil menyelidiki persoalan 'adil - dabit bid'ah - fasik menyalahi orang lain (syas), kesilapan, rawi tidak dikenal dan ada tuduhan bahwa sanadnya munqathi ${ }^{70}$ (bahwa rawinya mentadlis ${ }^{71}$ atau mengiras ${ }^{72}$ ).

\section{An-Naqad al-Dâkbili (Kritik Matan Hadits)}

Bagian ini lebih banyak berbicara hadits itu sendiri. apakah maknanya sabih atau tidak, dan apa jalan-jalan yang dilalui dalam menuju kesahihannya. Metode al-Naqad al-Dakbili hadits pada umumnya melakukan langkah "membandingkan" atau "pertanyaan silang" dan "referensi silang". Langkah teknis metode al-naqad al-

${ }^{68}$ M. Abdurrahman and Elan Sumarna, Metode Kritik Hadits, 14.

${ }^{69}$ M. Abdurrahman and Elan Sumarna, Metode Kritik Hadits, 57.

${ }^{70}$ Hadits yang gugur seorang atau dua orang dengan tidak berturut-turut di pertengahan sanad. Hal tersebut dinamai inqita. Mengetahui adanya inqita adalah dengan mengetahui ada tidaknya pertemuan antara seorang dan rawi lain. Hal ini adakalanya karena tidak semua atau tidak semua atau tidak pernah bertemu M. Hasbi Ash-Shiddieqy, Sejarah \& Pengantar Ilmu Hadits ... 170.

71 Haditsyang tidak disebut dalam sanad atau sengaja digugurkan oleh seorang rawi nama gurunya dengan cara memberi waham (keraguan) apakah dia mendengar sendiri Haditsitu dari orang yang disebut namanya itu M. Hasbi AshShiddieqy, Sejarah \& Pengantar Ilmu Hadits ... 170.

72 Haditsyang tidak bersambung sanadnya M. Hasbi Ash-Shiddieqy, Sejarah \& Pengantar Ilmu Hadits ... 170. 
dakbili dengan mengumpulkan semua yang berhubungan dengan materi atau informasi, kemudian secara hati-hati membandingkan dengan satu persatu dengan yang lain, satu informasi dinilai keakuratan sumber (rawi).

An-Naqad al-Dakbili oleh al-A'zami dijelaskan dengan metode perbandingan. Adapun metode-metode tersebut adalah: 1) perbandingan hadits-hadits dari berbagai sanad murid seorang ulama, 2) perbandingan pernyataan seorang ulama pada waktu yang berbeda, 3) perbandingan pengucapan lisan dengan dokumen tertulis, dan 4) perbandingan hadits dengan teks al Quran yang berkaitan. ${ }^{73}$ Selain menggunakan metode perbandingan, menurut al-A'zami an-Naqd alDakbili juga menggunakan penggunaan pendekatan rasio dalam mengkritisi kebenaran informasi. ${ }^{74}$

Naqd al-hadits memang merupakan metode dalam melakukan pemeriksaan terhadap kesahiban hadis tentang semua yang berkaitan dengan Rasulullah saw. Namun demikian, menurut hemat peneliti naqd al-badits dapat digunakan untuk mengukur kredibilitas informasi yang saat sekarang ini mengalami kebanjiran. Berdasarkan naqd albadits. pemeriksaan kredibilitas informasi ada tiga hal yaitu kredibilitas sumber, informan dan isi informasi. Kredibilitas sumber, yaitu melakukan penyelidikan terhadap kebenaran sumber-sumber yang digunakan informasi tersebut. Naqd al-badits, bisa menjadi metode kredibilitas informasi pada saat ini dengan menyesuaikan beberapa instrumen yang sesuai dengan kondisi zaman sekarang.

\section{Kesimpulan}

Islam telah mempunyai tradisi yang original untuk melakukan penyelidikan terhadap kredibilitas informasi, yaitu naqd al-hadits. Namun selama ini naqd al-hadits. sudah tidak digunakan setelah kitabkitab musnad sahih dan sunan ulama hadits muncul. Kitab-kitab tersebut diantaranya yaitu Musnad Ahmad, Muwatha, Shahih Bukhari. Shabih Muslim. Sunan Tirmizy, Abu Dawud, Nasai, Ibnu Majah, dan

${ }^{73}$ M. Mustafa al-A'zamî, Studies in Hadith Methodology and Literature, 52.

74 al-A'zami Studies in Hadith Methodology and Literature, 56; M. Mustafa alA'zamî, Studies in Hadith Methodology and Literature, 56. 
Darimi. Setelah itu Naqd al-hadits hanya menjadi wawasan keilmuan saja di kalangan akademisi Islam.

Metode naqd al-hadits menekankan kepada dua aspek. yaitu naqd al-kharijiyyun (kritik yang tidak mengenai isi hadits) dan naqd al-dakbili (kritik terhadap isi hadits). Naqd al-kharijiyyun melakukan kritik pada persoalan ketersambungan sanad dan kesiqaban rawi. Sedangkan naqd al-dakbili melakukan kritik terhadap matan dengan metode perbandingan, kesesuaian dengan al-Quran, hadits lain dan rasio.

Kondisi saat sekarang ini oleh sebagian para ahli disebut era informasi, di mana informasi begitu berlimpah. Di sisi lain juga marak terjadinya misinformasi dan disinformasi. Sehingga dibutuhkan metode untuk mencari informasi yang kredibel. Berdasarkan kondisi inilah, menurut penulis naqd al-hadits dapat digunakan sebagai metode kritik kredibilitas informasi. Namun demikian, metode naqd al-badits perlu disesuaikan dengan realitas, kebutuhan dan tantangan yang ada pada era informasi.

\section{Daftar Pustaka}

Abdurrahman, M., and Elan Sumarna. Metode Kritik. Hadits. Bandung: PT. Remaja Rosdakarya, 2013.

Ahmad, Amar. "Perkembangan Media Online Dan Fenomena Disinformasi (Analisis Pada Sejumlah Situs Islam)." Jurnal Pekommas Vol. 16, no. 3 (2013): 177-86.

al-A'zami, M. Mustafa. Studies in Hadith Methodology and Literature. Riyadh: The Other Press, 1977.

al-Isfhani, Ragib. Mufradat Alfaa Al-Quran. Damaskus: Dar al-Qalam, $425 \mathrm{H}$.

al-Khamisi, 'Abd Rahman. Mu'jam 'Ulum Al-Hadits an-Nabawi, Jeddah: Darul Andalus, $1419 \mathrm{H}$.

al-Manzur, Ibn. Lisan Al-'Arab. Vol. Juz 8. Beirut: Dar Shadr. 1300 $\mathrm{H}$.

Ash-Shiddieqy, M. Hasbi. Sejarah \& Pengantar Ilmu Hadits. Semarang: Pustaka Rizki Putra, 2009. 
Brahnam, Sheryl. "Building Character for Artificial Conversational Agents: Ethos, Ethics, Believability, and Credibility." Psychnology Journal 7, no. 1 (2009): 9-47.

Briggs, Asa. Sejarah Sosial Media,. Jakarta: Yayasan Obor Indonesia, 2000.

Bundy, Alan. "Drowning in Information, Starved for Knowledge: Information Literacy, Not Technology, Is the Issue." Victorian Association for Library Automation, 2000.

------. "Drowning in Information, Starved for Knowledge: Information Literacy, Not Technology, Is the Issue." 10th VALA Conference, (18 February 2000 2000).

Castillo, Carlos, Marcelo Mendoza, and Barbara Poblete. "Information Credibility on Twitter." In WWW2011,. Hyderabad, India: IW3C2, 2011.

Corder, Jim W. "Hunting for Ethos Where They Say It Can't Be Found." Rhetoric Review, vol. 7, no. 2 (1989): 299-316.

Cortada, James W Making the Information Society: Experience, Consequences, and Possibilities New York: Prentice Hall, 2002.

Dahlan, Ahmad, Dwi H Widyantoro, Suhono H Supangkat, and Benhard Sitohang. "Ranking the Online Documents Based on Relative Credibility Measures." Journal Of Ict Research And Applications 3, no. 1 (2009): 19-33.

Donovan, Gill "A Quarter of Web Surfers Are Looking for Religion, " National Catholic Reporter, , 112002.

Fitzgerald, Mary Ann. "Misinformation on the Internet: Applying Evaluation Skills to Online Information." Teacher Librarian 24, no. 3 (1997): 9.

Graham, Leah, and Panagiotis Takis Metaxas. "'“Of Course It's True; I Saw It on the Interent!"." Communication Of The Acm, Vol. 46, no. 5 (2003). 
Griffiths, Mark. Glued the Screen: A Investigation into Information Addiction Worldwide. Reuters. London: Reuters, 1997.

------. Glued the Screen: A Investigation into Information Addiction Worldwide, London:: Reuters, 1997.

Hungbo, Jendele "Credible News Measures: A Medium's Integrity." Nebula, Vol. 4, No. 1 (2007): 276-84.

Keshavarz, Hamid "How Credible Is Information on the Web: Reflections on Misinformation and Disinformation." Infopreneurship Journal, Vol. 1, no. 2 (2014).

Kiousis, Spiro "Public Trust or Mistrust? Perceptions of Media Credibility in the Information Age." Mass Communication And Society Vol. 4, no. No. 4 (2001).

Liew, Anthony "Understanding Data, Information, Knowledge and Their Inter-Relationships." Journal Of Knowledge Management Practice, Vol. 8, No. 2 (2007).

Losee, Robert M. "A Discipline Independent Definition of Information." Journal of The American Society For Information Science (1986-1998) 48, No. 3 (1997): 254.

Markowsky, George. "Information Theory." In Encyclopadia Britannica. Ultimate Reference Suite. Chicago: Encyclopædia Britannica, 2008.

McCroskey, James C, and Thomas J Young. "Ethos and Credibility: The Construct and Its Measurement after Three Decades." Communication Studies 32, no. 1 (1981): 24-34.

Metzger, M. J. "Making Sense of Credibility on the Web: Models for Evaluating Online Information and Recommendations for Future Research." Journal Of American Society For Information Science And Technology, 58, no. 13 (2007): 2078-91.

Metzger, Miriam J., and Andrew J. Flanagin. "Credibility and Trust of Information in Online Environments: The Use of Cognitive Heuristics, "Journal Of Pragmatics, Vol. 59 (2013): 210-20. 
Muslimin, M. "Perkembangan Teknologi Dalam Industri Media." Jurnal Teknik Industri Vol. 12, no. 1 (2011): 57-64.

Naisbitt, John. Megatrends. New York: Warner Communications Company. 1982.

Nassar, Islam A., Jamal A. Hayajneh, and KH. Almsafir Mahmoud. "Relation between Social Network and Da'wah to Islam a Case Study on Jordanian Students." International Journal On Islamic Applications In Computer Science And Technology, Vol. 1, no. 1 (2013): 9-18.

Othman, Fadlan Mohd, Ahmad Munawar Ismail, Latifah Abdul Majid, Mazlan Ibrahim, Mohd Arif Nazri, Haziyah Hussin, Sabri Mohamad, et al. "The Significance and Application of Takhrij Al-hadits $\backslash$ Sciences in Academic Research." Education Research Journal 2, no. 10 (2012): 338-43.

Oxford. Pocket Oxford Dictionary. Oxford: Oxford University Press, 1994.

Piper, Paul S. Better Read That Again: Web Hoaxes and Misinformation. Learned Information, 2001.

Rahman, Fatchur. Ikbtishar Mushthalahul-Hadits, Bandung: PT. AlMa'arif, 1970.

Rakhmat, Jalaluddin. Psikologi Komunikasi. Cet. 14. Bandung: PT. Remaja Rosdakarya, 1999.

Rieh, Soo Young, and David R Danielson. "Credibility: A Multidisciplinary Framework." Annual Review Of Information Science And Technology 41, no. 1 (2007): 307-64.

Roberts, W. Rhys Aristotle (Rhetoric), eBooks@Adelaide The University of Adelaide Library, 2014.

Rogers, Everett. "Communication Technology: The New Media in Society." New York: Free Press, 1986.

------. Communication Technology: The New Media in Society, New York: Free Press, 1986. 
Sahrani, Sohari. Ulumul Hadits Bogor: Ghalia Indonesia, 2010.

Kbbi (Kamus Besar Bahasa Indonesia) Offline 1.2.

Shuriye, Abdi O , and Mosud T Ajala. "Islam and the Cyber World." Journal Of Educational And Social Research, Vol. 4, no. 6 (2014): 513-20.

Standler, Ronald B. "Evaluating Credibility of Information on the Internet." (2004): 13. www.rbs0.com/credible.pdf

Sweeney, Latanya. "Information Explosion, " Confidentiality, Disclosure, And Data Access: Theory And Practical Applications For Statistical Agencies, (2001): 43-74.

Taufik, Tata. Etika Komunikasi Islam Kritik Terbadap Teori Komunikasi Barat Bandung: Sahifa, 2008.

Teo, Thompson SH, Vivien KG Lim, and Raye YC Lai. "Intrinsic and Extrinsic Motivation in Internet Usage." Omega vol. 27, no. 1 (1999): 25-37.

Tseng, Shawn, and B.J Fogg. "Credibility and Computing Technology." Communication af The ACM, Vol. 42, no. No. 5 (1999).

Unwin, George, Philip Soundy U., and David H. Tucker. "History of Publishing." In Encyclopedia Britannica 2008 Ultimate Reference Suite, Chicago: Encyclopædia Britannica, 2007.

Waddington, P. Dying for Information: An Investigation of Information Overload in the Uk and World-Wide, London: Reuters Business Information, 1996.

Wathen, C. N., and J. Burkell. "Believe It or Not: Factors Influencing Credibility on the Web.". Journal of the American society for information science and technology, 53, no. 2 (2002): 134-44.

Webster, Frank. Theories of Information Society, London: Routledge, 1995. 
Whitehead Jr, Jack L. "Factors of Source Credibility." Quarterly Journal Of Speech 54, no. 1 (1968): 59-63.

Wuryanta, Ag. Eka Wenats "Digitalisasi Masyarakat: Menilik Kekuatan Dan Kelemahan Dinamika Era Informasi Digital Dan Masyarakat Informasi." Jurnal Imu Komunikasi, Vol. 1, no. 2 (2004).

Zuhri, Saifuddin. "Predikat Hadis Dari Segi Jumlah Riwayat Dan Sikap Para Ulama Terhadap Hadis Ahad ". Subuf, vol. 20, no. 1 (2008). 